\title{
Meta Analisis Model Discovery Learning Untuk Meningkatkan Hasil Belajar IPA Siswa SD
}

\author{
Maria Risna Uly Naibaho $^{1)}$ Elvira Radia Hoesein ${ }^{2)}$ \\ 1) Pendidikan Guru Sekolah Dasar, Universitas Kristen Satya Wacana, Salatiga, Indonesia \\ E-mail:292016130@student.uksw.edu \\ 2) Pendidikan Guru Sekolah Dasar, Universitas Kristen Satya Wacana, Salatiga, Indonesia \\ E-mail: elvira.hoesein@uksw.edu
}

\begin{abstract}
Abstrak: Penggunaan model discovery learning membawa banyak pengaruh dalam dunia pendidikan bagi guru, salah satunya pada hasil belajar IPA siswa SD. Hasil tersebut dapat dilihat dari hasil beberapa penelitian. Penelitian-penelitian yang telah membuktikan serta menunjukan bahwa adanya peningkatan hasil belajar setelah menggunakan model discovery learning, maka fokus penelitian ini yaitu apakah penggunaan model discovery learning dapat meningkatkan hasil belajar IPA siswa SD. Penelitian ini bertujuan untuk menganalisis kembali penggunaan model discovery learning untuk meningkatkan hasil belajar IPA siswa SD dengan merumuskan hipotesis, mengumpulkan data, menguji hipotesis dan merumuskan kesimpulan. Penelitian ini menggunakan metode meta analisis yang merangkum dari berbagai hasil penelitian dengan studi dokumen data penelitian dari jurnal terkait penggunaan model discovery learning yang dipublikasikan di jurnal Nasional. Teknik pengumpulan data dengan menggunakan non tes yaitu dengan menelusuri jurnal elektronik melalui Google Cendekia dan Google Scholar serta studi dokumentasi di perpustakaan. Dari hasil penelusuran diperoleh 9 artikel serta 3 skripsi yang terkait dengan model discovery learning. Hasil uji ${ }^{{ }}$sig. $(2$-tailed $)(0,000)<\alpha(0,05)$ dan $t_{\text {hitung }}=-13,566<t_{\text {tabel }}=1.78229$ sehingga Ho di tolak. Hasil analisis ternyata model discovery learning mampu meningkatkan hasil belajar IPA siswa mulai dari yang terendah $22 \%$ sampai yang tertinggi 55\% dengan rata-rata 34\%. Dari perhitungan effect size terhadap 9 artikel serta 3 skripsi yang telah di analisis dihasilkan effect size rata-rata sebesar 4,73. Berdasarkan hasil penelitian menunjukan bahwa model discovery learning sangat berpengaruh positif terhadap hasil belajar IPA siswa.
\end{abstract}

Kata Kunci: discovery learning, hasil belajar IPA

\begin{abstract}
The use of discovery learning models has many influences, one of which is the learning outcomes of elementary school students. These results can be seen from the results of several studies. Researches that have proven and shown that there is an increase in learning outcomes after using the discovery learning model, the focus of this study is whether the use of discovery learning models can improve elementary students' science learning outcomes. This study aims to re-analyze the use of discovery learning models to improve elementary students' science learning outcomes by formulating hypotheses, collecting data, testing hypotheses and formulating conclusions. This study uses a meta-analysis method that summarizes various research results with a study of research data documents from journals related to the use of discovery learning models published in National journals. The technique of collecting data using non-test is by searching electronic journals through Google Scholar and Google Scholar as well as documentation studies in libraries. From the search results obtained 9 articles and 3 theses related to discovery learning models. The results of the $t$ sig. (2-tailed) test $(0.000)<\alpha(0.05)$ and tcount $=-13.566<$ t table $=1.78229$ so that Ho is rejected. The results of the analysis showed that the discovery learning model was able to improve students' science learning outcomes from the lowest $22 \%$ to the highest $55 \%$ with an average of $34 \%$. From the calculation of the effect size on the 9 articles and 3 theses that have been analyzed, the resulting effect size is an average of 4.73. Based on the research results, it shows that the discovery learning model has a very positive effect on students' science learning outcomes.
\end{abstract}

Keywords: discovery learning, science learning outcomes 


\section{I.PENDAHULUAN}

Berbagai penelitian pernahdilakukan pada model discovery learning yang digunakan dalam bidang pendidikan tersedia cukup banyak yang disajikan dalam bentuk jurnal-jurnal dan skripsi yang telah dipulikasikan. Namun belum banyak penelitian dan kajian lanjutan terhadap hasil-hasil penelitian sebelumnya untuk menguji keefektifan hasil penelitian tersebut. Penelitian yang sudah dilakuakan oleh peneliti nantinya hasilnya dapat dijadikan untuk pengguatan terhadap penelitian yang pernah dilakukan.Penelitian yang dapat ditempuh yaitu dengan metode meta analisis. Meta analisis merupakan metode penelitian yang terstuktur yang disertai dengan pengumpulan data untuk menghitung kesimpulan dari beberapa hasil penelitian yang telah dilakukan. Peneliti mengambil beberapa penelitian sesuai dangan judul yang dipakai dalam penelitian ini. Metode meta analisis ini digunakan oleh peneliti untuk merangkum poin-poin penting dari hasil penelitian yang pernah dilakukan.

Pendidikan merupakan salah satu usaha yang digunakan untuk memperbaiki kualitas sumber daya manusia. [1] Salah satu cara untuk memperoleh pendidikan adalah dengan mengikuti kegiatan pembelajaran di sekolah. Kegiatan pembelajaran di sekolah saat ini tidak lagi berpusat pada guru melainkan pada siswa. Selain itu, pembelajaran yang awalnya hanya dilakukan dengan cara ceramah sudah tergantikan dengan diterapkannya pendekatan ilmiah.

Pendidikan memegang peranan penting untuk mengembangkan potensi pada setiap individu. Melalui pendidikan seseorang akan berani dalam menghadapi serta memecahkan setiap permasalahan, karena pendidikan bertujuan membantu siswa dalam mengembangkan potensi yang dimilikinya. Dengan menempuh pendidikan, seseorang dapat terhindar dari rendahnya kemampuan kognitif dan kemiskinan. Pendidikan menjadi pembeda antara seseorang dengan orang yang lainnya, dilihat dari pengetahuan, kemampuan dan keterampilan yang dimilikinya sehingga dapat meningkatkan kesejahteraan. Salah satu adalah mata pelajaran adalah IPA.

[2] Pendidikan merupakan hal penting dalam kehidupan manusia. Melalui pendidikan seseorang dapat memperoleh pengetahuan yang kompleks. Suatu bangsa dapat menyiapkan sumber daya manusia yang lebih baik untuk membangun bangsa menjadi lebih baik lagi. Salah satu upaya yang dilakukan dalam membangun sumber daya manusia yang baik melalui peningkatan kualitas pendidikan di Indonesia.

Proses pembelajaran IPA merupakan kegiatan untuk mempelajari tentang gejala-gejala alam di permukaan bumi ini terjadi. Sehingga pembelajaran ini sangat penting untuk diperkenalkan sejak sedini mungkin tentang apa serta bagaimana pembelajaran IPA dikelas. Pengenalan melalui proses pembelajaran dapat dimulai atau diawali dengan mencari tahu tentang apa pengertian dari IPA. [3] menjelaskan IPA adalah kumpulan teori sistematis dalam penerapan secara umum terbatas pada gejala-gejala alam yang berkembang melalui metode ilmiah seperti observasi dan eksperimen. Selain itu, IPA menuntut siswa agar dapat mempunyai sikap ilmiah diantaranya adalah rasa ingin tahu, terbuka, jujur, dan sebagainya. Sementara itu, menurut [4] mengemukakan bahwa IPA adalah suatu pengetahuan yang diperoleh melalui proses pengumpulan data dengan melakukan eksperimen, pengamatan dan deduksi yang dapat menghasilkan sebuah penjelasan mnegenai suatu gejala alam yang dapat dipercaya. Pembelajaran IPA adalah proses memaknai alam maupun fenomena yang nampak, perilaku yang ada, serta karakteristik yang dikemas menjadi sebuah kumpulan teori dan konsep melalui beberapa proses ilmiah yang telah dilakukan oleh manusia [5]

Tujuan adanya pembelajaraan IPA di sekolah dasar adalah untuk memberikan pengalaman belajar secara langsung yaitu diberikan melalui penggunaan serta adanya pengembangan keterampilan proses dan sikap ilmiah. Pembelajaraan IPA di SD mengharapkan pada siswa agar dapat memperoleh pengalaman langsung sehingga pembelajaraan akan jauh lebih bermakna dan dapat melatih kemampuan berfikir siswa. Dengan tujuan lain agar siswa memiliki sikap saintis dalam diri siswa serta dikap saintis dapat terus meningkat dan berkelanjutan [6]. Untuk menciptakan suasana belajar mengajar yang bermakna maka dibutuhkan model pembelajaraan yang dapat menciptakan kondisi pembelajaran yang diharapkan.

Pembelajaran yang beorientasi target penguasaan materi terbukti berhasil dalam kompetensi jangka pendek, tetapi gagal dalam membekali anak memecahkan persoalan dalam jangka panjang, hal ini di karenakan siswa tidak benar-benar memahami materi yang disampaikan guru. Selain itu pemberian materi juga harus diperhatikan, hal ini untuk menghindari dalam hal kesalahan atau kekurangan penerimaan konsep pada siswa dengan benar dan tetap memperhatikan psikologi siswa dimulai dari pembukaan sampai evaluasi di akhir pembelajaran, jadi pembelajaran yang bermakna adalah pembelajaran yang terdapat satu kerjasama atau interaksi antara siswa dengan siswa, siswa dengan guru, sehingga akan tercipta suasana kelas yang lebih hidup dan bermakna bagi siswa. Selain itu proses pembelajaran diharapkan dapat berjalan sistematis, komprehensif, dan terpadu dalam proses pembelajaran menuju kedewasaan dan keberhasilan dalam kehidupan di masyarakat.

Guru memiliki peranan penting dalam proses pembelajaran guna mewujudkan tujuan pendidikan. Penerapan model pembelajaran dalam kegiatan pembelajaran merupakan hal yang sangat penting sehingga dapat meningkatkan hasil belajar, karena dengan model tersebut guru dapat menciptakan suatu kondisi belajar yang mendukung pencapaian dalam tujuan pembelajaran. [7] guru mempunyai peran yang sangat penting dalam proses pembelajaran. Apabila guru bekerja secara profesional maka sekolah dapat menghasilkan siswa yang unggul. Sebaliknya, guru di sekolah tidak dikelola dengan baik, maka output siswa disekolah itu pun akan rendah. Dengan kata lain, ada sebuah korelasi antara guru dan siswa, dimana guru membutuhkan manajemen yang baik untuk mencapai kualitas siswa yang baik. Belajar adalah suatu proses perubahan di dalam kepribadian yang berupa kecakapan, sikap, kebiasaan, 
dan kepandaian yang bersifat menetap dalam tingkah laku yang terjadi sebagai suatu hasil dari latihan atau pengalaman. Pembelajaran diartikan proses komunikasi dua arah, mengajar dilakukan oleh pihak guru sebagai pendidik, sedangkan belajar dilakukan oleh siswa atau murid [8].

Peningkatan hasil belajar yang baik tidak hanya didukung oleh kemauan siswa untuk mau belajar dengan baik, tetapi metode atau model pembelajaran yang digunakan oleh guru juga mempengaruhi hasil belajar siswa. [9] model pembelajaran adalah suatu rancangan kerangka dalam melaksanakan pembelajaran dalam model tersebut berisi langkah-langkah pembelajaran yang sistematis, mengorganisasikan dari pengalaman belajar dengan tujuan mencapai tujuan atau kompetensi yang diharapkan, dan dijadikan sebagai pedoman dalam pelaksanaan pembelajaran.Agar lebih memperhatikan dalam pembelajaran. Belajar dengan permainan yang dirancang dalam pembelajaran kooperatif memungkinkan dapat belajar lebih santai disamping menumbuhkan tanggung jawab, kejujuran, persaingan sehat dan keterlibatan belajar.

Model pembelajaran merupakan landasan praktik pembelajaran hasil penurunan toeri psikologi pendidikan dan teori belajar yang dirancang berdasarkan analisis terhadap implementasi kurikulum dan implikasinya pada tingkat operasional di kelas. Model pebelajaran dapat diartikan pula sebagai pola yang digunakan untuk penyusunan kurikulum, mengatur materi, dan memberi petujuk kepada guru di kelas. [10] model pembelajaran merupakan seluruh rangkaian kegiatan pembelajaran dalam penyajian materi yang seperti segala aspek sebelum, sedang dan sesudah pembelajaran yang dilakukan guru serta segala fasilitas yang terkait yang digunakan baik secara langsung maupun secara tidak langsung dalam proses pembelajaran.

Kegiatan pembelajaran yang mengajak siswa untuk menemukan sebuah pengalaman baru ini sangat membantu untuk meningkatkan hasil belajarnya, dikarenakan melalui belajar penemuan, siswa dilatih untuk belajar secara mandiri dengan mencoba memecahkan sendiri masalah yang dihadapi sehingga akan mendapatkan pemahaman yang lebih baik karena mereka dilibatkan secara langsung untuk menyelesaikan masalah yang sedang dihadapi. [11]. Menurut [12] discovery learning adalah sebuah model pembelajaran yang dalam penerapanya mengarahkan siswa untuk berfikir secara Kritis, dimana dalam kegiatan pembelajaranya siswa diarahkan untuk lebih aktif dalam mengidentifikasi sendiri pemahaman tentang suatu masalah yang dibahas dalam kegiatan pembelajaran sejalan dengan [13] discovery learning adalah Model yang berkembang dari pandangan Kontruktivisme, yang dimana kegiatan belajar mengajar berfokus pada keaktifan siswa dalam memahami suatu konsep dalam pembelajaran. [14] model discovery learning adalah model kegiatan belajarnya melibatkan siswa dalam proses kegiatan mental melalui pendapat dengan berdiskusi, membaca sendiri dan mencoba sendiri, agar siswa dapat belajar sendiri. [15] discovery learning adalah model dimana melibatkan siswa untuk pemecahan masalah sehingga dapat pengembangan pengetahuan serta ketrampilan. [16] model discovery learning dalam kegiatan pembelajarannya akan melibatkan seluruh potensi kemampuan para siswa dalam rangka mencari serta menemukan sesuatu (benda, manusia, atau peristiwa) secara sistematis, kritis, logis, analitis, dengan demikian para siswa dituntun agar dapat merumuskan penemuannya sendiri dengan sertai keyakinan dengan penuh percaya diri.Pada modeldiscovery learning melibatkan siswa dalam proses kegiatan mental melalui tukar pendapat, dengan diskusi, membaca informasi dari berbagai sumber sendiri, ataupun melakukan pengamatan dan percobaan sendiri.Model discovery learningadalah salah satu cara dalam mengembangkan kreatifitas dan keaktifan siswa melalui proses menemukan, menyelidiki sendiri, sehingga hasil yang diperoleh bertahan lama dalam ingatan dan siswa tidak akan mudah lupa [17] selanjutnya menurut [18] menjelaskan bahwa discovery learning adalah model yang memberikan kesempatan pada seluruh siswa untuk terlibat secara langsung dalam proses pembelajaran, dengan demikian para siswa mampu memanfaatkan proses mentalnya dalam menemukan konsep serta teori yang sedang dipelajari. Sementara itu,Lingkungan seperti ini agar memudahkan siswa di dalam proses belajar sehingga proses pembelajaran dapat berjalan dengan baik dan lebih kreatif [19].

[20] model discovery learning adalah proses yang di awali mulai dari merumuskan masalah, mengembangkan hipotesis, mengumpulkan bukti, menguji hipotesis, dan menarik kesimpulan sementara, menguji kesimpulan sementara supaya sampai pada kesimpulan yang diyakini oleh siswa. [21] Penerapan model discovery learning dapat dilakukan oleh guru pada saat proses pembelajaran di kelas untuk meningkatkan kualitas proses pembelajaran yang lebih membuat aktif dan bermakna bagi siswa. [22] menyatakan bahwa model discovery learning dengan diawali guru memberikan pertanyaan untuk merangsang berpikir siswa kemudian meminta siswa untuk membaca buku materi selanjutnya melakukan aktivitas belajar lainnya. siswa mengidentifikasi masalah sesuai dengan bahan pelajaran dan merumuskannya ke dalam hipotesis. Kemudian, siswa mengumpulkan informasi yang relevan untuk membuktikan benar tidaknya hipotesis tersebut dilanjutkan pengolahan data yang diperoleh melalui wawancara, observasi dan sumber data lainnya, guru melakukan pemeriksaan dengan cermat untuk membuktikan benar tidaknya hipotesis yang ditetapkan dengan hasil dan pengolahan data, guru bersama siswa menarik kesimpulan untuk dijadikan prinsip umum yang berlaku untuk semua masalah yang sama.

\section{METODE}

Jenis penelitian ini menggunakan metode meta analisis yaitu upaya merangkum berbagai hasil penelitian dengan studi dokumen yang digunakan peneliti yaitu 12 data terkait penggunaan model discovery learning. Teknik pengumpulan data dengan menggunakan non tes yaitu dengan menelusuri jurnal elektronik melalui Google Cendekia dan Google Scholar serta studi dokumentasi di perpustakaan dengan menggunakan kata kunci "discovery learning", dan "Hasil Belajar IPA Siswa SD". Dari hasil penulusuran diperoleh 12 artikel yang relevan yang sudah diterbitkan. 
Teknik analisis data dengan memenggunakan metode pembanding kuantitatif untuk mengetahui seberapa besar pengaruh model discovery learning. Analisis dilakukan dengan membandingkan selisih skor nilai sebelum tindakan pembelajaran dengan sesudah tindakan pembelajaran menggunakan model discovery learning. Setelah itu, dibagi dengan skor sebelum tindakan pembelajaran menggunakan model discovery learning (dalam bentuk \%) untuk mengetahui presentase peningkatan hasil belajar IPA siswa SD.

\section{HASIL DAN PEMBAHASAN}

Hasil penelitian mendapatkan 9 artikel jurnal serta 3 skripsi yang berhubungan dengan penggunaan model discovery learning dalam meningkatkan hasil belajar IPA siswa SD. Selanjutnya data artikel tersebut diolah dengan cara merangkum dan mencantumkan intisari hasil penelitian model discovery learning. Kemudian data dilaporkan kembali dengan cara deskriptif kualitatif dankuantitatif. Berikut data hasil analisis model discovery learning:

Tabel 1. Presentase Peningkatan Hasil Belajar Siswa

\begin{tabular}{|c|c|c|c|c|c|}
\hline \multirow{2}{*}{ No } & Peneli & \multicolumn{4}{|c|}{ Peningkatan Hasil Belajar } \\
\cline { 3 - 6 } & & $\begin{array}{c}\text { Semul } \\
\mathbf{a}\end{array}$ & $\begin{array}{c}\text { Sesud } \\
\text { ah }\end{array}$ & $\begin{array}{c}\text { Gai } \\
\mathbf{n}\end{array}$ & $\begin{array}{c}\text { Gain } \\
\text { \% }\end{array}$ \\
\hline 1 & $\mathrm{X} 1$ & 59,50 & 74,80 & 15,3 & 26 \\
\hline 2 & $\mathrm{X} 2$ & 64,64 & 78,75 & $\begin{array}{c}14,1 \\
1\end{array}$ & 22 \\
\hline 3 & $\mathrm{X} 3$ & 63,63 & 80,73 & $\begin{array}{c}17,1 \\
0\end{array}$ & 27 \\
\hline 4 & $\mathrm{X} 4$ & 62,40 & 81,64 & $\begin{array}{c}19,2 \\
4\end{array}$ & 31 \\
\hline 5 & $\mathrm{X} 5$ & 53,93 & 73,12 & $\begin{array}{c}19,1 \\
9\end{array}$ & 36 \\
\hline 6 & $\mathrm{X} 6$ & 63,50 & 88,70 & $\begin{array}{c}25,2 \\
0\end{array}$ & 40 \\
\hline 7 & $\mathrm{X} 7$ & 59,29 & 80,47 & $\begin{array}{c}18,2 \\
1\end{array}$ & 31 \\
\hline 8 & $\mathrm{X} 8$ & 63,50 & 88,70 & $\begin{array}{c}25,2 \\
0\end{array}$ & 40 \\
\hline 9 & $\mathrm{X} 9$ & 55,33 & 85,66 & 30,3 & 55 \\
\hline 10 & $\mathrm{X} 10$ & 56,60 & 83,00 & $\begin{array}{c}26,4 \\
0\end{array}$ & 47 \\
\hline 11 & $\mathrm{X} 11$ & 61,50 & 78,40 & $\begin{array}{c}16,9 \\
0\end{array}$ & 27 \\
\hline 12 & $\mathrm{X} 12$ & 64,20 & 79,40 & $\begin{array}{c}15,2 \\
0\end{array}$ & 24 \\
\hline & $\mathrm{Mean}$ & 60,66 & 81,11 & $\begin{array}{c}20,1 \\
9\end{array}$ & 34 \\
\hline
\end{tabular}

Berdasarkan tabel 1 di atas, menunjukkan bahwa model discovery learningmampu meningkatkan Hasil Belajar IPA Siswa Sekolah Dasar. Presentase rata-rata peningkatan hasil belajar IPA siswa dengan menggunakan model discovery learning mulai dari yang terendah $22 \%$ sampai yang tertinggi $55 \%$ dengan rata-rata 20,19\%. Rata-rata hasil belajar siswa sebelum menggunakan modeldiscovery learning $60,66 \%$ meningkat menjadi $81,11 \%$. Nilai rata-rata sebelum pembelajaran dengan model discovery learning dan sesudah pembelajaran menggunakan model discovery learning mengalami peningkatan yang signifikan sebesar $34 \%$.

Hasil ini sejalan dengan hasil penelitian yang dilakukan oleh [23] yang berjudul Meta Analisis Pengaruh Pendekatan Discovery Learning terhadap Kemampuan Berpikir Kritis Siswa Kelas V Tematik Muatan IPA. Hasil ini menunjukan bahwa terjadi pengaruh kemampuan berpikir kritis siswa yang berbeda-beda dengan nilai rata-rata mulai dari yang terendah 5,35\% sampai yang tertinggi 32,19\% dengan ratarata sebesar 108.68\%. Hasil uji T Sig.(2-tailed) $(0,000)<\alpha$ $(0,05)$ dan thitung $=3,935<$ tabel $=2.785$ sehingga Ho di tolak. Jadi, dapat disimpulkan bahwa terdapat perbedaan kemampuan berpikir kritis muatan pelajaran IPA siswa sebelum dan sesudah menggunakan pendekatan discovery learning. selain itu, hasil penelitian menunjukan bahwa pendekatan discovery learning sangat berpengaruh positif terhadap kemampuan berfikir kritis siswa.

Proses keterlibatan siswa saat pembelajaran berlangsung akan memberikan dampak positif bagi siswa, karena siswa akan mudah memahami materi yang sedang dipelajarinya. Kelebihan model discovery learning ini akan sangat membantu siswa dalam mengembangkan; memperbanyak kesiapan; serta penguasaan keterampilan dalam proses kognitif atau pengenalan siswa, siswa dapat memperoleh pengetahuan yang bersifat sangat pribadi atau individual sehingga dapat melekat pada jiwa siswa, dapat meningkatkan gairah belajar siswa, mampu memberikan kesempatan kepada siswa untuk berkembang sesuai dengan kemampuannya masing-masing selain itu dapat membantu siswa untuk menambah kepercayaan pada dirinya sendiri. [24]. Hal ini ditunjukan dari hasil analisis uji beda. Berikut hasil Output Paired-Sampel T Test yaitu:

Tabel 2. Paired Samples Statistics

\begin{tabular}{|c|c|c|c|c|c|}
\hline & & Mean & $\mathrm{N}$ & $\begin{array}{c}\text { Std. } \\
\text { Deviation }\end{array}$ & $\begin{array}{l}\text { Std. Error } \\
\text { Mean }\end{array}$ \\
\hline \multirow[t]{2}{*}{$\begin{array}{l}\text { Pair } \\
1\end{array}$} & Pretetst & $\begin{array}{c}60,668 \\
3\end{array}$ & 12 & 3,69846 & 1,06765 \\
\hline & $\begin{array}{c}\text { Posttes } \\
\mathrm{t}\end{array}$ & $\begin{array}{c}81,114 \\
2\end{array}$ & 12 & 4,86004 & 1,40297 \\
\hline
\end{tabular}

Tabel 2 di atas menunjukkan bahwa pembelajaran dengan menggunakan model discovery learningmampu meningkatkan hasil belajar IPA siswa dari nilai rata-rata 60,6683 menjadi 81,1142 .

Tabel 3. Paired Samples Correlations

\begin{tabular}{ccccc}
\hline & & N & Correlation & Sig. \\
\hline $\begin{array}{c}\text { Pair } \\
1\end{array}$ & $\begin{array}{c}\text { Pretetst \& } \\
\text { Posttest }\end{array}$ & 12 &, 279 &, 379 \\
\hline
\end{tabular}

Tabel 3 menunjukkan adanya relasi antara hasil belajar IPA rata -rata sebelum dengan sesudah menggunakan modeldiscovery learning sebesar 0,279. Hasil uji hipotesis, $\mathrm{HO}=$ tidak terdapat perbedaan yang signifikan hasil belajar 
IPA siswa sebelum pembelajaran menggunakan model discovery learning dan $\mathrm{H} 1=$ terdapat perbedaan yang signifikan hasil belajar IPA siswa sebelum pembelajaran menggunakan model discovery learning.

Tabel 4. Paired Samples Test

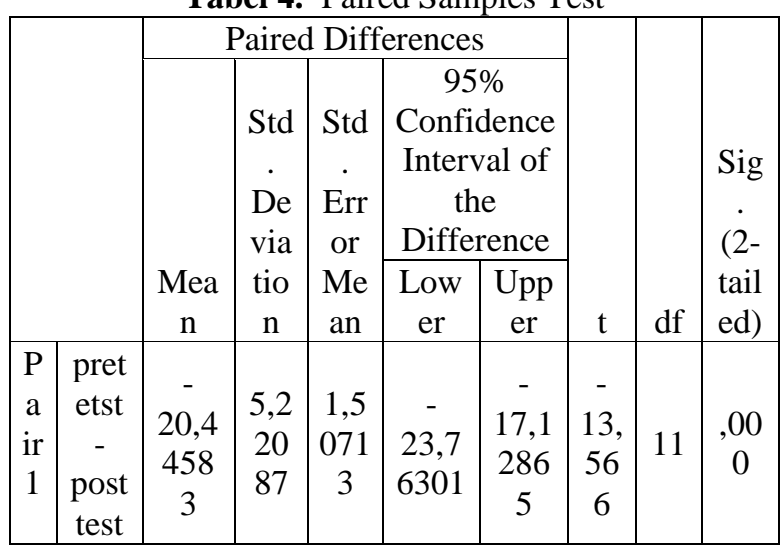

Tabel 4 menunjukkan bahawa nilai $\mathrm{t}$ hitung $=-13,566<\mathrm{t}$ tabel $=1.78229$ maka Ho ditolak. Jadi dapat disimpulkan bahwa terdapat perbedaan yang signifikan hasil belajar IPA siswa sebelum pembelajaran dengan menggunakan model discovery learning dan sesudah pembelajaran menggunakan model discovery learning. Mean skor hasil belajar sesudah penggunaan model discovery learning lebih tinggi (lebih baik) dari pada sebelum penggunaan model discovery learning. Hal itu diperlihatkan pada tabel Paired Sample Statistics. Mean skor hasil belajar IPA sebelum penggunaan model discovery learning adalah sebesar 60,6683 sedangkan mean skor hasil belajar IPA sesudah penggunaan model discovery learning adalah sebesar 81,1142. Artinya, bahwa penggunaan model discovery learning memilki pengaruh positif. Pengaruh (effect size) sebesar 4,73.Dengan demikian dapat disimpulkan bahwa pengaruh positifnya dalam kategori sangat tinggi. Artinya, model discovery learning tersebut memiliki pengaruh positif yang sangat tinggi dalam meningkatkan hasil belajar IPA siswa. Hasil analisis data ini dapat disimpulkan bahwa terdapat pengaruh model discovery learning pembelajaran untuk meningkatkan hasi belajar IPA siswa.

Model discovery learning dapat meningkatkan hasil belajar IPA siswa, hal ini dapat dilihat dari hasil belajar siswa yang terus meningkat dalam setiap tindakan yang dilakukan. Pemilihan model yang tepat menjadi salah satu faktor yang berpengaruh terhadap aktivitas siswa dalam pembelajaran. Salah satu model pembelajaran yang dapat diterapkan dalam pembelajaran di SD yakni model discovery learning yang dapat melibatkan siswa aktif untuk mencari dan menemukan sendiri masalah atau konsep yang harus mereka pahami dengan menekankan pada proses dan hasil belajar. Menurut [25] menyatakan bahwa model discovery learning menekankan pentingnya pemahaman suatu konsep melalui keterlibatan siswa secara aktif dalam proses pembelajaran. Selain itu, model pembelajaran ini menekankan pada pembentukan pengetahuan siswa dari pengalaman selama pembelajaran sehingga penerapan model discovery learning dalam pembelajaran diharapkan dapat membangkitkan motivasi belajar sehingga hasil belajar siswa menjadi lebih meningkat, khusunya siswa Sekolah Dasar.

Berdasarkan pada hasil-hasil penelitian, dapat ditunjukan dari setiap hasil penelitian memperoleh hasil peningkatan presentase hasil belajar yang berbeda-beda. Peningkatan hasil berlajar pun berbeda-beda, ada yang besar dan hanya cukup dalam peningkatannya. Hal ini di mungkukan dapat dipengaruhi oleh faktor internal merupakan faktor yang berasal dari dalam diri siswa yang meliputi kemampuan, bakat, minat serta kondisi fisik kesehatan tubuh kemudian faktor eksternal merupakan faktor yang berasal dari luar diri siswa seperti keluarga, sekolah dan lingkungan masyarakat [26]. Lokasi serta tempat penelitian yang berbeda-beda ini tentu akan memberikan berpengaruh pada hasil penelitian demikian juga pada data yang didapatkan. Selanjutnya berdasarkan kemampuan para siswa dari berbagai daerah itu berbeda dan dapat berpengaruh terhadap perolehan hasil belajar. Penelitian yang dilakukan dari daerah yang berbeda-beda juga berpengaruh terhadap hasil penelitian yang diperoleh. Hasil belajar IPA siswa di setiap daerah juga berbeda .

Peningkatan hasil belajar IPA siswa berdasarkan pada temuan penelitian menunjukan dari perolehan rata-rata besarnya pengaruh model discovery learning sebesar 4,73. Angka ini memberikan makna bahwa perlakuan model discovery learning dalam pembelajaran mampu meningkatkan hasil belajar IPA pada siswa SD sebesar 4,73. Dengan demikian dapat dikatakan bahwa model discovery learning sangat efektif dalam proses kegiatan belajar mengajar dan memperoleh kategori harga effect size yang tinggi.Penelitian meta-analisis mengungkapkan dan melaporkan bahwa penerapan model discovery learning ternyata dapat meningkatkan dan memberikan kontribusi hasil belajar siswa SD.

\section{SIMPULAN}

Kesimpulan yang diperoleh dari penelitian ini adalah hasil analisis meta menunjukkan bahwa penerapan bahwa modeldiscovery learning telah dilakukan oleh para peneliti mampu meningkatkan hasil belajar siswa SD mulai dari yang terendah terendah $22 \%$ sampai yang tertinggi 55\% dengan rata-rata $34 \%$. Rata-rata hasil belajar siswa sebelum menggunakan model discovery learning 60,66\% meningkat menjadi $81,11 \%$. Nilai rata-rata sebelum pembelajaran dengan model discovery learning dan sesudah pembelajaran menggunakan model discovery learning mengalami peningkatan yang signifikan sebesar $34 \%$. Dari perhitungan effect size terhadap 9 artikel dan 3 skripsi yang telah di analisis dihasilkan effect size rata-rata sebesar 4,73.

Berdasarkan hasil penelitian menunjukan bahwa model discovery learningsangat berpengaruh positif terhadap hasil belajar IPA siswa. Adapun saran yang disampaikan dari hasil penelitian ini yakni hendaknya dapat menjadikan model discovery learning sebagai model yang dapat menumbuhkan kreatifitas serta motivasi yang menyenangkan sehingga dapat meningkatkan hasil belajar kemudian pada guru hendaknya dapat menggunakan model discovery learning ini pada proses pembelajaran untuk dapat meningkatkan kualitas pembelajaran serta meningkatkan hasil belajar siswa melalui 
model discovery learning. Model discovery learning perlu diterapkan di sekolah, hal ini dikarenakan langkah-langkah dalam model discovery learning sesuai untuk melatih kemampuan berpikir kritis siswa dan siswa belajar secara aktif dalam memperoleh pengetahuan. Guru dapat mengunakan model discovery learning dalam variasi pemilihan model pembelajaran untuk meningkatkan motivasi dan hasil belajar siswa. Siswa diharapkan untuk lebih meningkatkan hasil belajarnya. Bagi penelitian atau berikutnya yang akan melakukan penelitian dibidang ini, diharapkan penelitian ini dapat menjadi gambaran, informasi dan masukan tentang penggunaan model discovery learning dalam pembelajaran selanjutnya agar dapat mengikut sertakan lebih banyak artikel dan hasil skripsi lagi. Hal ini bertujuan agar data yang diperoleh lebih banyak, lebih luas dan dapat dilihat lebih dalam tentang hasil penelitiannya.

\section{DAFTAR PUSTAKA}

[1] Sani, R, A. (2014). Inovasi Pembelajaran. Jakarta: BumiAksara.

[2] Kristin, F. (2016). Analisis Model Pembelajaran Discovery Learning Dalam Meningkatkan Hasil Belajar Siswa SD. Jurnal Pendidikan Dasar PerKhasa 2, ( 1), 90-98.

[3] Purwasari, Y. (2013). Meningkatkan Hasil Belajar IPA Tentang Perubahan Kenampakkan Permukaan Bumi dan Benda Langit Melalui Peta Pikiran pada Anak Kesulitan Belajar Kelas IV SD 13 Balai-Balai Kota Padang Panjang. Jurnal Ilmiah Pendidikan Khusus. 1 (1): 536548 .

[4] D. Indriati S, C, P. (2012). Meningkatkan Hasil Belajar IPA Konsep Cahaya Melalui Pembelajaran ScienceEdutainment Berbantuan Media Animasi. Jurnal Pendidikan IPA Indonesia. 1 (2): 192-197.

[5] Mariana, A, M, I \& Praginda, W. (2009). Hakikat IPA dan Pendidikan IPA Untuk Guru SD. Bandung: Pusat Pengembangan dan Pemberdayaan Pendidik dan Tenaga Kependidikan IPA (PPPPTK IPA).

[6] Santiasih, N, L. Marheani, A, A, I, N \& Tika, I, N. (2013). Pengaruh Model Inkuiri Terbimbing terhadap Sikap Ilmiah dan Hasil Belajar IPA Peserta didik Kelas V SD No.1 Kerobokan Kecamatan Kuta Utara Kabupaten Bandung Tahun Pelajaraan 2013/2014. PENDASI: Jurnal Pendidikan Dasar Indonesia , 1(1).

[7]Astuti, S. (2017) Supervisi Akademik Untuk Menigkatkan Kompetensi Guru di SD Laboratorium UKSW Scholaria, 7 (1),: $49-59$.

[8] Sagala, S. (2012). Konsep dan Makna Pembelajaran, Bandung : Alfabeta.

[9] Mawardi. (2018). Merancang Model dan Media Pembelajaran. Scholaria: Jurnal Pendidikan dan Kebudayaan, 8(1), 28 \& 40.

[10] Istarani. (2011). 58 Model Pembelajaran Inovatif. Medan: Media Persada.

[11] Anugraheni, I. (2018).Meta Analisis Model Pembelajaran Problem Based Learning Dalam Meningkatkan Keterampilan Berpikir Kritis Di Sekolah Dasar [A Meta-Analysis Of Problem Based Learning
Models In Increasing Critical Thinking Skills In Elementary Schools]. Jurnal Polyglot, 14,(1), 9-18.

[12] Arindah, A. (2016). Pengaruh Penerapan Model Discovery Learning Terhadap Hasil Belajar Siswa Pada Mata Pelajaran IPS Kelas IV SD. Jurnal Penelitian Pendidikan Guru Sekolah Dasar, 3(2)

[13] Yupita, I, A. (2013). Penerapan model pembelajaran discovery untuk meningkatkan hasil belajar IPS di sekolah dasar. Jurnal Penelitian Pendidikan Guru Sekolah Dasar, 1(2), 1-10

[14] Sibuea, S, K. Syaukani \& Nasution, W, N. (2019). Penerapan Model Discovery Learning dalam Pembelajaran Sejarah Kebudayaan Islam di MTs Darul Hikmah TPI Medan. Edu-Riligia 3 (3), 386-393.

[15] Effendi, S \& Tukiran. (2012). Metode Penelitian Survei. Jakarta : LP3ES.

[16] Rohim, F. Susanto, H \& Ellianawati. (2012). Penerapan Model Discovery Terbimbing pada Pembelajaran Fisika Untuk Meningkatkan Kemampuan Berpikir Kreatif. Unnes Physics Education Journal. 1 (1): 1-5.

[17] Vahlia, I. (2014). Ekperimentasi Model Pembelajaran Discovery dan Group Investigation terhadap Prestasi Belajar Matematika Ditinjau dari Kreativitas Siswa: Aksioma. 3 (2): 43-54

[18] Ilahi, M, T \& Sawitri, N. (2012). Pembelajaran Discovery Strategi \& Mental Vocational Skill. Jogjakarta: Diva Press.

[19] Hosnan, M. (2014). Pendekatan Saintifik dan Kontekstual dalam Pembelajaran Abad 21. Bogor: Ghalia Indonesia

[20] Sinambela, P, NJM. (2017). Kurikulum 2013 dan Implementasinya dalam Pembelajaran. Generasi Kampus, $6(2)$.

[21] Mubarok, C \& Sulistyo, E. (2014). Penerapan Model Pembelajaran Discovey Learning Terhadap Hasil Belajar Siswa Kelas X TAV Pada Standar Kompetensi Melakukan Instalasi Sound System Di SMK Negeri 2 Surabaya. Jurnal Pendidikan Teknik Elektro, 3, 215 221 .

[22] Siahaan, F, B. (2017). Application of Discovery Learning Model for Solving System of Linear Equations Using Geo Gebra. International Journal of Applied Engineering Research, 12(19), 9195-9198

[23] Noviyanto, W, Y \& Wardani, N, S (2020) Meta Analisis Pengaruh Pendekatan Discovery Learning terhadap Kemampuan Berpikir Kritis Siswa Kelas V Tematik Muatan IPA. TSCJ, 3(1), hal 2615-6105.

[24] Roestiyah, N, K. (2012). Strategi Belajar Mengajar. Jakarta: Rineka Cipta.

[25] Puspitadewi, R. Saputro, A, N, C \& Ashadi. (2016). Penerapan Model Pembelajaran Discovery Learning untuk Meningkatkan Minat dan Prestasi Belajar Siswa Pada Materi Kelarutan dan Hasil Kali Kelarutan Kelas XI MIA 3 Semester Genap SMA N 1 Teras Tahun Pelajaran 2015/2016. Jurnal Pendidikan Kimia, Universitas Sebelas Maret. Volume 5,(4), hal.115.

[26] Atmojo, S, E. (2014). Pembelajaran IPA Berbasis Konseling Untuk Membentuk Pemahaman Tentang 


\section{Jurnal Pendidikan Dasar Indonesia}

Volum 6 Nomor 1 bulan March tahun 2021. Page 19 - 25

p-ISSN: 2477-5940 e-ISSN: 2477-8435

Pubertas Pada Siswa Sekolah Dasar. Elementary

School: Jurnal Pendidikan dan Pembelajaran ke-SD-

an, $1(1)$. 